\title{
Dynamics of Public Space Occupation Economic Purposes in Bogota, Colombia
}

\author{
Amelec Viloria ${ }^{1 *}$ and Germán Álvarez² \\ 'Escuela de Negocios de la Fundación Universitaria Konrad Lorenz., Bogotá, Colombia; \\ amelecj.viloras@konradlorenz.edu.co \\ 2Instituto Tecnológico Metropolitano, Medellín, Colombia; germanalvarez@itm.edu.co
}

\begin{abstract}
Objectives: The main purpose of this article, which develops from system dynamics, is to make recommendations to serve for the design of public policies on the occupation of physical space by informal sellers of goods for immediate consumption in Bogota. Methods/Statistical Analysis: The process was divided into four (4) phases Defining the problem and identification of the actors, their interests and decision rules, Construction of the causal diagram cycles and description of results. Findings: The most important results indicate that greater interaction among the various stakeholders would be useful in reducing the occupation and the Mayor of Bogota should pay special attention to the time of working life passing traders working in the public space, as this delay may end up condemning this population to work indefinitely in the streets and sidewalks of the city. Application/Improvements: The presence of street vendors of goods for immediate consumption in an area of public space has serious implications on the success of relocation programs, because it increases the likelihood that a passerby buy on the street, because his decision who to buy it is especially based on the proximity of the point of sale.
\end{abstract}

Keywords: Delays, Feedback Loops, Informal Sales, Public Space, System Dynamics

\section{Introduction}

Studies and proposals that have been made on the issue of sales and $\mathrm{n}$ informal public space in Bogotá ${ }^{1}$, include unemployment or inability of the formal labor sector to absorb the available labor as a fundamental reason for the existence of this activity. In this sense, it is known that $74 \%$ of street vendors in the public space $n$ employees and had previously been the formal labor market ${ }^{2}$

In addition, the high rate of migration to the city puts an enormous burden on the absorptive capacity of the formal labor market. Thus Bogota in the last 100 years "has increased more than 50 population and its density has doubled, from 149 to 345 people per hectare"

This research is part of a project to reduce economic purposes occupation of public space in Bogotá, Colombia. This article corresponds to the first phase of the project is a case study on informal sales in the public space by traders of goods for immediate consumption (food vendors made on site, candy, cigarettes and newspapers, especially) and its effects on the invasion of sidewalks and pedestrian platforms capital of Colombia, and its ultimate goal to make recommendations for the design of public policies that help reduce the level of occupation and allow, in turn, meet the rights that conflict.

In this sense, through this proposal that is made from system dynamics, we propose a different way of addressing the problem, including identification of the actors and their interests, and the description and analysis of the structure of system, which is defined through the causal relationships that exist between the different variables and feedback loops present and delays.

\section{Theoretical Foundation}

In order to make it more clear the approach of the dynamic hypothesis, which is done in the next aside, it is important to define the variables used, as follows:

${ }^{*}$ Author for correspondence 
EP Occupation: Number of informal and relocated traders who are occupying public space at a particular time.

Chance to buy street: The probability that a passerby buy products at an informal vendor occupying public space.

TransReubic: Number of passersby who buy products to vendors relocated.

Chance Success Reubic: Probability of successful relocation program sellers of goods for immediate consumption.

Output VI Reubic to VIEP: Departure from vendors relocated to the town of informal vendors who are occupying public space.

VIEP: Number of street vendors occupying the public space.

VIEP to VI Reubic output: Output street vendors who are occupying public space to the town of vendors relocated.

VI Reubic EP Occupation: Number of relocated vendors occupying the public space.

TrabFor VIEP output: Output of formal workers to the population of informal vendors occupying public space.

Output to total inactivity: Departure from informal vendors who are occupying public space to retirement.

VIEP to Trab For time: time to spend informal vendor in the public space formal worker.

Capital assets Impairment: Measurement of deterioration of work experience and educational level of a person.

VPO Govt: Value perceived by the authorities of the number of street vendors and relocated working in the public space at a particular time.

EP occupation VIEP Control Effect of control of public space by informal vendors in the level of employment.

Trans PCBS effect: effect on the level of occupation of public space in the number of pedestrians moving through an area.

Trans: Number of pedestrians moving through a sector.

TransCalle: Number of passersby who buy products from street vendors.

Production Emp Form: Effect of the production level of formal company in the occupation of public space.

\section{Methodology}

Phase 1 and 2: Defining the problem and identification of the actors, their interests and decision rules.
For the realization of phase 1 and 2 different documents on labor informality and especially informal public space sales they were consulted. Thus, decrees of the Mayor and agreements of the Council of Bogota, judgments of the Council of State and the Constitutional Court of Colombia, documents of the Chamber of Commerce of Bogota, reports Bogotá reviewed "Cómo Vamos", studies CEPAL and ONU-Habitat.

In addition, reports from the observatory of the labor market and social security of the Externado University of Colombia, magazine articles Development and Society and the Center for Economic Development Studies of the University of the Andes were studied, and congresses System Dynamics society. It is important to note that this review was made especially for the period 2005-2014, however, some older sources also consulted this period were considered very relevant.

Finally, in order to corroborate or rectify the information found in the review of documents, some semi-structured interviews to street vendors in 2014 and various monitoring activities between 2010 and 2014 were performed.

Phase 3: Construction of the causal diagram cycles: From the definitions made in phase 2 and consultation articles on Dynamic Systems corresponding to 2005-2014, especially in databases Science Direct and Wiley Online Library, they defined each of the variables and system delays, and the causal diagram cycles was performed using software version 1.0.0.1 Vensim.

Phase 4: Description of the results, final thoughts and implications: The purpose of this phase was to explain in detail the results obtained from the formulation of the dynamic hypothesis, primarily, in other words through the explanation the structure of the system, as shown in the diagrams of cycles causes of the previous phase. Similarly, specific recommendations for the design of public policies on control and recovery of public space were raised.

\section{Results and Discussion}

From the characterization of the problem made earlier and from an operational perspective, we can say that the actors who are part of the system of occupation of public space by informal vendors of goods for immediate consumption in Bogotá, as well as their respective interests are those shown in Table 1.

In this first part of the results it is important to note that the proposals on the solution to the problem under 
Table 1. Actors and interests of the problem under study

\begin{tabular}{|c|c|}
\hline Actors & Interests \\
\hline $\begin{array}{l}\text { Informal vendors of } \\
\text { goods for immediate } \\
\text { consumption in public } \\
\text { space }\end{array}$ & $\begin{array}{c}\text { Earn income to sustain them and } \\
\text { their families through sales of } \\
\text { products marketed }\end{array}$ \\
\hline $\begin{array}{l}\text { Sellers relocated } \\
\text { immediate } \\
\text { consumption goods }\end{array}$ & $\begin{array}{c}\text { Earn income to sustain them and } \\
\text { their families through sales of } \\
\text { products marketed }\end{array}$ \\
\hline passers & $\begin{array}{l}\text { Move freely within the public } \\
\text { space and buy the products } \\
\text { marketed by the informal traders, } \\
\text { vendors relocated or commercial } \\
\text { establishments }\end{array}$ \\
\hline Business establishments & $\begin{array}{c}\text { Sell the products they sell to } \\
\text { passersby }\end{array}$ \\
\hline $\begin{array}{l}\text { Formal production } \\
\text { company }\end{array}$ & $\begin{array}{c}\text { Sell the products they make } \\
\text { passers }\end{array}$ \\
\hline Mayor of Bogotá & $\begin{array}{l}\text { Reduce the occupation of public } \\
\text { space, design and implement } \\
\text { programs of relocation and } \\
\text { formalization }\end{array}$ \\
\hline
\end{tabular}

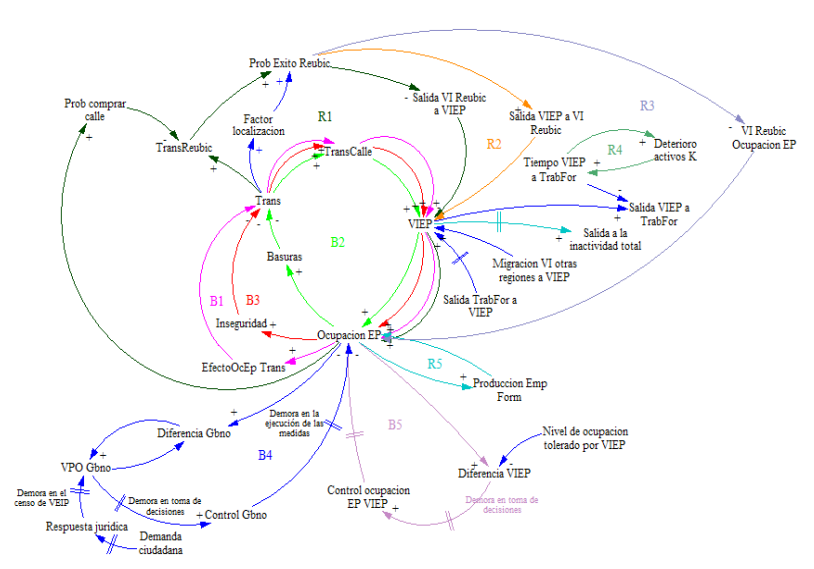

Figure 1. Diagram causal cycles.

study have been made on the need to establish policies or encourage actions involving exclusively to informal vendors occupying public space and Town hall. In this regard, as will be presented later when the dynamic hypothesis explaining this traditional look is inadequate since the problem by the reactions it arises precisely because of the conflict of interest between the actors, including those who typically have not been considered, and They presented in the system to actions or attitudes of a particular actor.

Now, to describe the behavior of the variable occupation of public space for street vendors (called
Occupation EP), essential to explain variable, will proceed to study the structure of the system, i.e., the causal relationship that exists between the variables, present feedback loops and delays. Hence in Figure 1 causal loop diagram is presented.

\section{Conclusions}

The presence of street vendors of goods for immediate consumption in an area of public space has serious implications on the success of relocation programs, because it increases the likelihood that a passerby buy on the street, because his decision who to buy it is especially based on the proximity of the point of sale.

Therefore, the number of pedestrians who buy the relocated vendors will be lower, so that the income of this group of sellers are going to be reduced, decreasing the likelihood of success of alternative employment and generating as a consequence, a greater number of reallocated sellers leave the program and try to occupy the streets (cycle R1) again, that street vendors occupying public space wary of this labor alternative and then a smaller group of the population intends to do part of it (cycle R2); moreover, that a percentage of the relocated vendors occupy the physical space of the city (cycle R3). In short, three feedback loops which reinforce the problems are generated.

Similarly, some delays in the system make the level of informal vendors in the public space tends to increase rapidly and the outputs are slow. As for the delays to go to work as street vendors in the public space, workers who come from the formal labor market (Exit TrabFor to VIEP) enter e $\mathrm{n}$ a while, just 2 years. Even in ${ }^{4}$, it is considered that no formal traders migrating from other regions (VI Migration VIEP other regions) do directly to work in informal sales, therefore his intention is to enter work immediately.

Instead, there are long delays associated with the exit of public space. On the one hand, there is a long delay to get into total inactivity (output to total inactivity) since most informal vendors do not pay pension, then the way to get your basic old - age income will be Aves his work

On the other hand, the time to spend informal vendor in the public space formal worker (Time VIEP to TrabFor) is also important and depends critically on the capital assets of the population of informal vendors, i.e., experience formal labor and education; also, the longer their working life through an informal trader working in the public space, there will be a further deterioration of their capital assets. Then, a vicious cycle that can end up 
condemning the population to work in informal activities in public space ( $\mathrm{R} 4$ cycle) occurs.

However, the high level of informal vendors in the public space is also due to the ineffectiveness of the mechanisms of control of the authorities. In this sense, although in some localities of Bogota regular checks on areas Reclaim as previously done, in ${ }^{\underline{6}}$ major projects recovery of public space and offer alternative employment for informal traders have followed a process that presents diverse and long delays (cycle B4).

Generally, the process begins with a demand that interposes a citizen against the corresponding Local Municipality with the aim of recovering an area of public space. And then after a while, the appropriate legal response, which is required to Local Mayor implementing recovery measures of public space in the respective area and design work options for those affected, is generated.

Subsequently, a measurement of the number of street vendors who are occupying public space is performed. Then comes a period in which the information collected and case reports (delay in the census VIEP) are generated to report the perceived value of the number of traders who occupy public space (VPO Govt) is processed; then there is a delay in decision-making by the design or adjustment of programs with labor alternatives and control of public space (Control Govt) and, finally, the number of street vendors and relocated occupying public space compared against to that received by the authorities (Difference Government), and the corresponding measures are taken to regulate or balance the system value.

Then, between each of these stages there are major delays and between the first and the last action to execute will be several years. Similarly, informal vendors are interested in controlling the occupation of public space. The cycle balance B5 shows that the control process of informal traders began with the establishment of a kind of level tolerated by workers in the public space and compares it intuitively but steadily, with the number of street vendors and relocated to occupy the streets (difference VIEP) and, from this, take measures of corresponding control $^{\mathrm{T}}$.

In this sense, this research is postulated that measurements and process control them street vendors may be more accurate and effective than the Mayor, because it is they who are all the time in the field, which allows the realization measurements frequently and take immediate action (if any), thereby reducing delays that may arise in the process control; also by the need for this population to limit the number of people entering the public space work to prevent their income is put at risk.

Other cycles balance generated by the presence of informal sales in public space are associated with the direct and indirect impact on reducing the number of bystanders who come to a zone, which affects not only sales of commercial establishments and vendors relocated, but also of the same vendors who work on the streets. The first cycle is caused by the same occupation of public space (cycle $\mathrm{B} 1$ ), which creates problems for the free movement and discourages the number of pedestrians moving through a sector, and the second and the third, refer to a increase in the amount of waste (cycle B2) and increase in the level of insecurity (B3 cycle).

Finally, the problem must be addressed not only with a view of demand, but also with the prospect of supply of products sold (cycle R5), since both passersby, who are buying the products offered, as formal production company, which manufactures consumer goods immediately and gets great economic benefits by marketing them in the public space, play a fundamental role in the system.

\section{References}

1. Donovan M. Space wars in Bogota: The recovery of public space and its impact on street vendors. Available from: www.harvard.edu/fs/docs/icb.topic233886.files /April_22/ Donovan_Space_sp08.pdf

2. Castaneda A, Garcia J. Habitat and public space: The case of informal vendors in the public space of Bogotá, Bogotá. Javeriana Cultural Arts Foundation; 2007.

3. Chamber of Commerce of Bogotá. Memories forum experiences in business and labor formalization in cities of Latin America: Business and labor formalization builds prosperous regions. Available from: www.bibliotecadigital.ccb.org. co/handle/11520/2845

4. Chamber of Commerce of Bogotá. Effect of street sales of commercial establishments in four areas of the city of Bogota, Bogota. Horizons Graphics S.ENC.S; 2005

5. Farne S. Participation of seniors in market economies and home in Colombia, Bogotá: Universidad Externado de Colombia; 2014

6. El Tiempo. Informal vendors Chapinero, enter 'waist'? Available from: www.eltiempo.com/archivo/documento/ CMS-13570655

7. Weather. Informal vendors Chapinero, enter 'waist'? Available from: www.eltiempo.com/archivo/documento/ CMS-13570655 